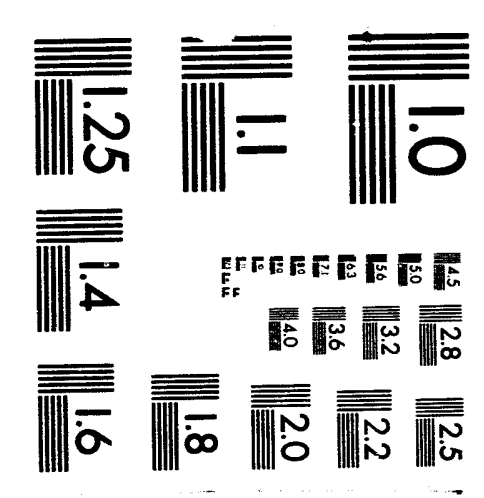



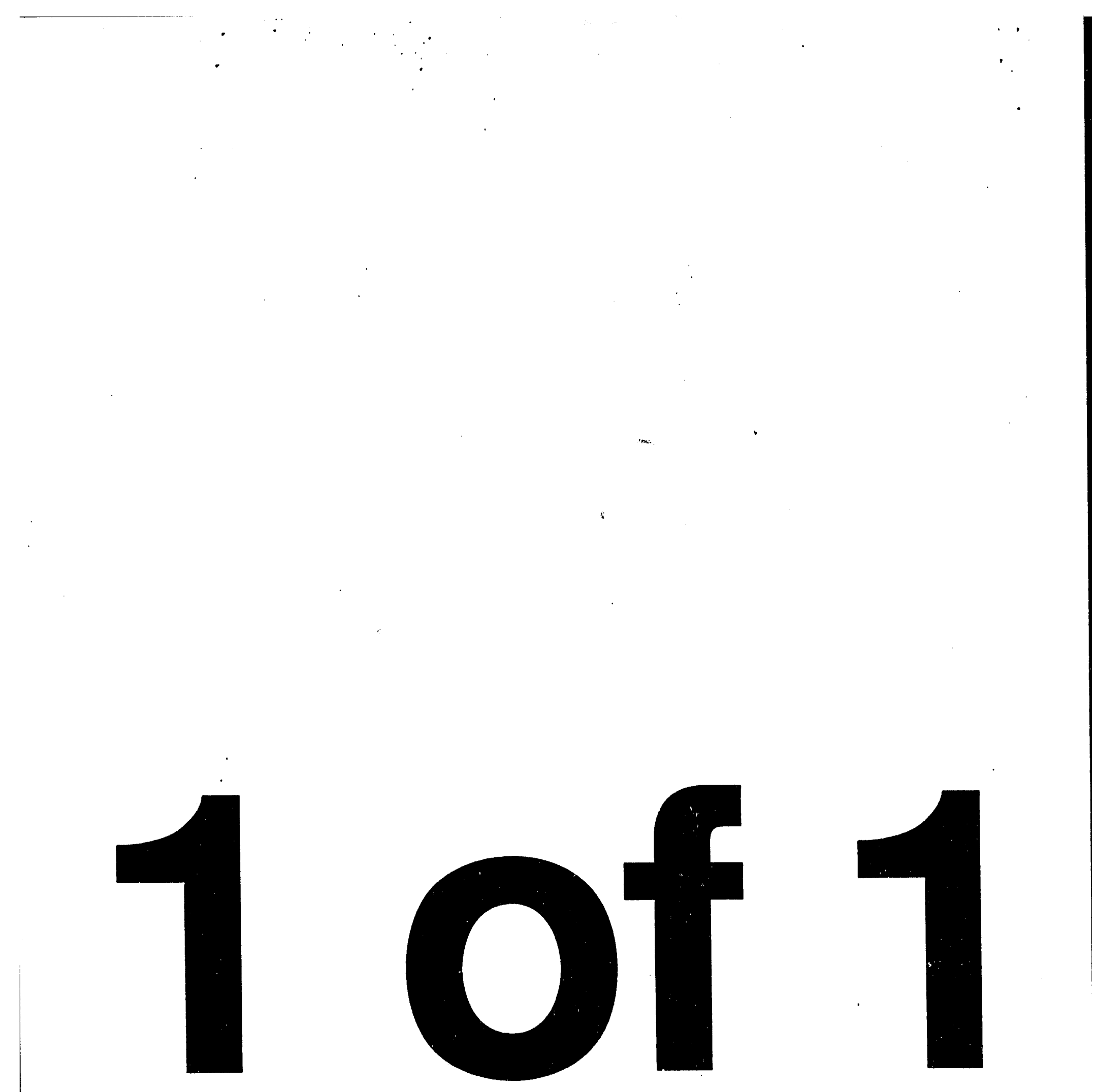


\title{
Battery Energy Storage and Superconducting Magnetic Energy Storage for Utility Applications: A Qualitative Analysis
}

\author{
Abbas A. Akhil \\ Paul Butler \\ Storage Batteries Department \\ Thomas C. Bickel \\ Photovoltaic Technology Research Department \\ Sandia National Laboratories \\ Albuquerque, New Mexico 87185
}

\begin{abstract}
This report was prepared at the request of the U.S. Department of Energy's Office of Energy Management for an objective comparison of the merits of battery energy storage with superconducting magnetic energy storage technology for utility applications. Conclusions are drawn regarding the best match of each technology with these utility application requirements. Staff from the Utility Battery Storage Systems Program and the Superconductivity Programs at Sandia National Laboratories contributed to this effort.
\end{abstract}




\section{Contents}

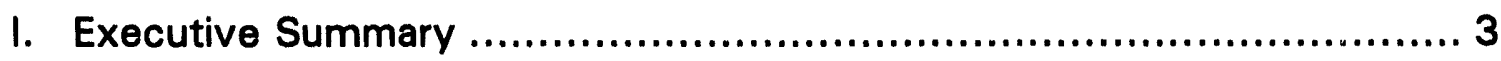

Results....................................................................... 5

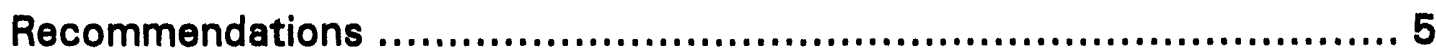

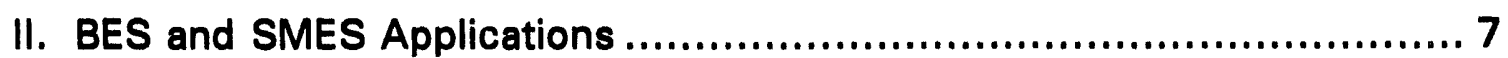

Background ............................................................ 7

Requirements and Applications ......................................... 10

III. Technology Status and Development Needs ............................. 13

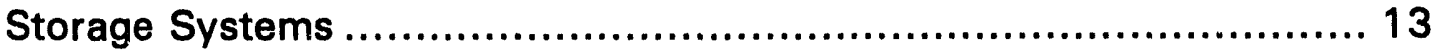

Power Conversion fo; BES and SMES ................................. 15

\section{Tables}

1 Utility Applications and Corresponding Preliminary Energy Storage

Requirements ................................................................ 3

2 Utility Applications and Storage Technology Suitability ................... 4

3 Utility Battery Projects - Existing \& Planned ............................. 8

4 Utility SMES Projects — Existing \& Planned.................................. 9

\section{Figures}

1 Schematic of a BES System ............................................ 14

2 Schematic of a SMES System........................................... 14 


\section{EXECUTIVE SUMMARY}

This report compares the merits of battery energy storage (BES) and superconducting magnetic energy storage (SMES) for utility applications. Although pumped-hydro is the only mature energy storage technology currently available to utilities, it has not been considered in this report because of severe siting, environmental, and size constraints. Based on this BES/SMES comparison, recommendations are made to the U.S. Department of Energy (DOE) regarding possible DOE involvement in development of the two technologies for specific utility applications. Developmental needs for each technology and its interface to the utility grid (the power conditioning subsystem) are also identified.

As a result of demonstration projects and system studies, utilities have realized that energy storage can be used for many applications. Table 1 shows representative utility applications and preliminary energy storage requirements that have evolved from these demonstrations and studies. More important, utilities have realized that they can use one energy storage device for more than one application. This makes energy storage an option to attain higher efficiencies and reduce operating costs for utilities. If suitable energy storage systems are developed to meet these application requirements, they can satisfy the needs of a potentially large segment of the electric utility market and have a significant impact on utility operations nationally.

Table 1. Utility Applications and Corresponding Preliminary Energy Storage Requirements

\begin{tabular}{||l|c|c|c||}
\hline \multicolumn{1}{|c|}{ Utility Application } & \multicolumn{3}{|c|}{ Energy Storage Requirements } \\
\hline & $\begin{array}{c}\text { Energy } \\
\text { Capacity } \\
\text { (MWh) }\end{array}$ & $\begin{array}{c}\text { Avg. Discharge } \\
\text { Time } \\
\text { (h) }\end{array}$ & $\begin{array}{c}\text { Max. } \\
\text { Discharge Rate } \\
\text { (MW) }\end{array}$ \\
\hline Load Leveling & $>40$ & $4-8$ & $>10$ \\
\hline Spinning Reserve & $<30$ & $0.5-1$ & $<60$ \\
\hline Frequency Regulation & $<5$ & $0.25-0.75$ & $<20$ \\
\hline Power Quality & $<1$ & $0.05-0.25$ & $<20$ \\
\hline $\begin{array}{l}\text { Substation Application } \\
\text { (e.g., transformer deferral, } \\
\text { feeder/customer peak } \\
\text { shaving, etc.) }\end{array}$ & $<10$ & $1-3$ & $<10$ \\
\hline Renewables & $<1$ & $4-6$ & $<0.25$ \\
\hline
\end{tabular}


The ability of BES and SMES technologies to meet these needs depends on their basic characteristics (energy density, round-trip efficiency, and rate of charge and discharge) and their performance. An estimate of the suitability of BES and SMES technologies for specific utility applications is presented in Table 2. The suitability estimate is based on technical merit, recognizing that BES is further developed. Consideration has been given to the potential for overcoming technical hurdles facing SMES before it achieves a mature status. Economic issues were not addressed in this analysis.

Table 2. Utility Applications and Storage Technology Suitability

\begin{tabular}{|r|c|c|c|c|}
\hline Utility Application & \multicolumn{2}{|c|}{ BES } & \multicolumn{2}{c|}{ SMES } \\
\hline & $\begin{array}{c}\text { Current } \\
\text { Tech }\end{array}$ & $\begin{array}{c}\text { Advanced } \\
\text { Tech }\end{array}$ & $\begin{array}{c}\text { Current } \\
\text { Tech }\end{array}$ & $\begin{array}{c}\text { Advanced } \\
\text { Tech** }\end{array}$ \\
\hline Load Leveling & UN & ND & UN & NA \\
\hline Spinning Reserve & SA & ND & ND & ND \\
\hline Frequency Regulation & SA & ND & SA & ND \\
\hline Power Quality & SA & ND & SA & ND \\
\hline $\begin{array}{r}\text { Substation } \\
\text { Applications }\end{array}$ & SA & ND & ND & ND \\
\hline Renewables & SA & ND & ND & NA \\
\hline
\end{tabular}
UN = Unsuitable
SA = Suitable, Available
ND $=$ Needs Development
$\mathrm{NA}=$ Needs Assessment
*Low Temperature Superconductors * *High Temperature Superconductors

BES could meet the performance requirements for most of the applications in Table 1. The concerns of utilities about reliability, life, and energy density for particular applications have driven development of improved lead-acid and advanced batteries. SMES could meet the requirements for applications that require rapid charging and discharging. If significant advances are made, then SMES could be used in other applications. The required materials for large superconductors have driven the development needs.

Both BES and SMES systems require future development. The concerns of utilities about BES reliability, life, and energy density for particular applications have driven development of improved lead-acid batteries. For SMES systems, the required materials for large superconductors have driven development needs.

For either SMES or BES to be useful to a utility, an interface between the storage device and the grid must be present. The interface is the power conversion subsystem (PCS). PCSs are commercially available, but current designs are not cost-effective. Advances in technology such as the resonant 
frequency power converter suggest that the major development needs are to provide manufacturers with standardized requirements and to demonstrate PCS capabilities to utilities as part of integrated system demonstration programs.

\section{Results}

In general, BES is well suited for applications that require fast response as well as storage capacities up to approximately three hours. Present BES systems based on lead-acid batteries can meet all the utility application requirements except load leveling. In the near term, the primary needs of this technology are for developing standardized, integrated system designs that can be purchased by utilities on a turn-key basis. Further support for field demonstrations at utility sites to validate performance is highly desirable. In the longer term, sustained development of advanced battery technologies, such as sodium/sulfur and zinc/bromine, is needed to ensure that improved-performance battery systems will be available to meet anticipated utility needs.

SMES offers rapid charge/discharge capabilities, but is limited by storage capacity. Considerable development effort will be required to increase SMES capacity beyond its present capability of a few seconds to approximately three hours in order to meet certain utility application requirements.

Widespread application of both technologies requires development of off-theshelf PCS hardware and vendor capability. The one-of-a-kind $\mathrm{r} C \mathrm{~S}$ that was built for earlier battery projects will not be able to meet the needs of the energy storage market as it grows. Cost-effective PCS hardware with higher functionality will be needed.

\section{Recommendations}

This analysis suggests that both SMES and BES are storage technologies that can meet specific needs of the electric utility industry. The deployment of these technologies will result in better asset utilization in the utility network. To facilitate efficient deployment of these systems, SNL recommends the following course of action for consideration by the DOE:

- Assist the utility industry, component manufacturers, and system suppliers to develop and demonstrate standardized BES systems for specific applications using commercially available and near-term batteries.

- Continue development of BES systems with advanced batteries to meet the performance needs of high-capacity, small-footprint applications. 
- Develop and validate cost models for SMES including further refinement of cold support/warm support trade-offs, magnet geometries, and refrigeration systems.

- Pursue development of SMES technologies for intermediate-to-long discharge duration applications, if warranted by the cost models.

- Assess the feasibility of SMES for large-scale energy storage and, if warranted, initiate a core-technology development program to address critical technology needs.

- Determine the research and development issues related to power conditioning subsystems that would facilitate the development of costeffective, standardized PCSs for energy storage and renewable energy applications. Initiate a DOE-supported program for PCS technology improvements, if warranted. 


\section{BES AND SMES APPLICATIONS}

\section{Background}

Utilities have traditionally thought of BES systems only for load-leveling applications. Recent studies 1,2 have identified at least five other applications, which are shown in Table 1. Benefit studies have shown that energy storage systems can satisfy more than one of these applications, thereby greatly increasing their economic value to a utility network.

There has been an effort to demonstrate the feasibility of using BES and SMES energy storage technologies. Table 3 lists most of the BES systems that are in use or planned by utilities. This list covers a broad range of applications in which BES offers benefits to utilities. However, it does not include BES systems used on the customer side of the meter, such as UPSs, or those used with industrial customers for peak shaving to reduce their demand charges. It also excludes a large number of battery systems at military bases that are used as a UPS or as a supplement for special needs such as pulse power for experimental submarines or other experiments that cannot be supplied with commercial utility power.

Table 4 lists SMES projects that are completed or planned. The Superconductivity, Inc., devices are leased to selected demonstration sites and tested. The other projects are in the planning or conceptual stage.

1 Four system studies performed in FY91-92 with San Diego Gas \& Electric, Oglethorpe Power Corporation, Chugach Electric Association and Bonneville Power Administration, SAND93-1754.

2 SMES Utility/Industry Applications Workshop, September 2-3, 1992. 
Table 3. Utility Battery Projects - Existing \& Planned

\begin{tabular}{|c|c|c|}
\hline Company Name & MW/MWh & $\begin{array}{l}\text { On-Line or } \\
\text { Planned }\end{array}$ \\
\hline \multicolumn{3}{|l|}{ I. Projects Completed } \\
\hline Crescent Electric Coop. & $0.5 / 0.5$ & 1983, Operating \\
\hline Southern California Edison (Chino) & $10 / 40$ & 8/86, Operating \\
\hline Berlin Power and Light (BEWAG) & $\begin{array}{l}8.5 / 8.5 \\
17 / 5.7 \\
\end{array}$ & 2/87, Operating \\
\hline San Diego Gas \& Electric Trolley Load-Leveling Project & $0.20 / 0.40$ & 11/92, Operating \\
\hline \multicolumn{3}{|l|}{ Tatsumi Substation (Kansai Electric) } \\
\hline Lead-acid & $1 / 4$ & 1986. Operating \\
\hline Sodium/sulfur & $1 / 8$ & 1991, Completed \\
\hline \multicolumn{3}{|l|}{ Imajuku Energy Storage Test Plant (Kyushu Electric Power Co.) } \\
\hline Zinc/Bromine & $1 / 4$ & 1991, Completed \\
\hline Puerto Rico Electric Power Authority, 1st of 5 Planned Installations & $20 / 14.1$ & $\begin{array}{c}11 / 93 \text { (Under } \\
\text { Const.) }\end{array}$ \\
\hline \multicolumn{3}{|l|}{ II. Committed to Conceptual Design } \\
\hline Chugach Electric Association, Anchorage, AK & $10 / 20$ & 7/94, Planned \\
\hline Hawaii Electric Light Company & $10 / 10$ & 4/94, Planned \\
\hline Puerto Rico Electric Power Authority, 2nd Planned Installation & $20 / 14.2$ & 1/95, Planned \\
\hline Metlakatla Power \& Light, Metlakatla Village, AK & $1 / 1 / 60$ & 1/94, Planned \\
\hline Tlingit, Haida Regional Electrical Authority, Kasaan Village, AK & $0.03 / 0.09$ & 1/94, Planned \\
\hline Pacific Gas \& Electric Utility Scale Battery Demonstration & $2 / 4$ & 3/94, Planned \\
\hline \multicolumn{3}{|l|}{ III. Completed System Study } \\
\hline Oglethorpe Power Corporation & $6 / 19$ & $?$ \\
\hline San Diego Gas \& Electric, System-Wide Benefits & $20 / 60$ & $?$ \\
\hline Consolidated Edison & $?$ & $?$ \\
\hline New York Power Authority, Metro North Railway Application & $2 / 4$ & $?$ \\
\hline Bonneville Power Authority, Puget Sound Area Study & $?$ & $?$ \\
\hline
\end{tabular}


Table 4. Utility SMES Projects - Existing \& Planned

\begin{tabular}{|c|c|c|}
\hline Project Name & $\begin{array}{l}\text { Power Rating/Stored } \\
\text { Energy }\end{array}$ & $\begin{array}{c}\text { Status } \\
\text { On-Line or Planned }\end{array}$ \\
\hline Superconductivity, Inc. & $\begin{array}{l}460-2500 \mathrm{KVA} \\
140-550 \mathrm{Wh}\end{array}$ & Commercial Product \\
\hline $\begin{array}{l}\text { Los Alamos National Laboratory/ } \\
\text { Bonneville Power Authority }\end{array}$ & $\begin{array}{c}10 \mathrm{MVA} \\
30 \mathrm{MJ}(8.3 \mathrm{kWh})\end{array}$ & 1983-1984 \\
\hline $\begin{array}{l}\text { ABB, Zurich } \\
\text { Swiss National Railroad }\end{array}$ & $\begin{array}{c}1.2 \mathrm{MW} \\
210 \mathrm{MJ}(50 \mathrm{kWh})\end{array}$ & $\begin{array}{c}1993-1995 \\
\text { (Demonstration Unit) }\end{array}$ \\
\hline $\begin{array}{l}\text { ABB, Zurich } \\
\text { Swiss National Railroad }\end{array}$ & $\begin{array}{c}25 \mathrm{MW} \\
3600 \mathrm{MJ}(1 \mathrm{MWh})\end{array}$ & $\begin{array}{c}\text { Awaiting } \\
\text { Demonstration Results }\end{array}$ \\
\hline Hydro Quebec & $\begin{array}{c}10 \text { MVA } \\
33 \mathrm{MJ}(9 \mathrm{kWh})\end{array}$ & $\begin{array}{c}\text { 1993-1995 } \\
\text { (Demonstration Unit) }\end{array}$ \\
\hline Hydro Quebec & $\begin{array}{c}300 \mathrm{MVA} \\
360 \mathrm{MJ}(100 \mathrm{kWh})\end{array}$ & 2000 \\
\hline MITI-ISTEC & $\begin{array}{c}20 \mathrm{MW} \\
420 \mathrm{MJ}(120 \mathrm{kWh})\end{array}$ & 1994 \\
\hline ETM - DNA & $\begin{array}{l}10-400 \mathrm{MW} \\
20 \mathrm{MWh}\end{array}$ & ???? \\
\hline
\end{tabular}

ABB $=$ Asea Brown Boveri
MITI $=$ Ministry of International Trade and Industry (Japan)
ISTEC $=$ International Superconductivity Technology Center
DNA $=$ Defense Nuclear Agency
ETM $=$ Engineering Test Model




\section{Requirements and Applications}

Based on the demonstrations and studies, requirements and applications for energy storage systems have been summarized in this section.

Six utility applications of BES and SMES and corresponding preliminary system-performance requirements are shown in Table 1. A brief description of each application and the feasibility of using either a BES or SMES in each application follows.

Load Leveling. Utilities in tive size range of 2,000 to 3,000 MW typically need 300 to $400 \mathrm{MW}$ of generation capacity for at least 4 hours to meet their peak demand. Any form of storage capacity used to displace this peaking generation capacity must be fully capable of carrying this load until the peak period passes. Thus, the commonly accepted requirement for a storage system is at least $40 \mathrm{MWh}$ of storage capacity, capability for diurnal discharge, and displacement of $10 \%$ or more of the peak demand.

Load leveling requiring more than $40 \mathrm{MWh}$ is not easily attained with current lead-acid battery technology. Typically, this size of battery plant requires more than 8,000 batteries, and such a large number of batteries in one facility poses several design problems. These problems include ground fault detection and an unacceptably high number of parallel strings, leading to unbalanced charging. Even if these issues were successfully overcome, utilities are hesitant to accept the maintenance burden perceived with the operation of such a large battery plant. The development of improved and advanced batteries that reduce the size and complexity of the plant could make BES a favorable option for load leveling at some future time.

SMES has been proposed as a candidate for load-leveling applications, and the concept of SMES for large-scale load leveling has progressed to the point of engineering design of an Engineering Test Model (ETM). Originally designed for dual military/civilian use, the ETM has been designed for 20.4 $\mathrm{MWh}$ with a military power requirement of $400 \mathrm{MW}$ and a civilian requirement of at least $10 \mathrm{MW}$ for utility load leveling. The objective of the ETM is to validate the engineering design of an advanced SMES. However, the small size and experimental nature of the device leads to an inefficient unit, and its daily energy consumption may exceed its diurnal storage capacity. System sizes in excess of several hundred $\mathrm{MWh}$ for an efficient advanced SMES may be necessary to overcome the inefficiencies of the smaller sized systems. 
Spinning Reserve. Utilities are required by law to have 15 to $20 \%$ of their generating capacity readily available. Because this capacity is commonly held ready in rotating turbines, it is known as spinning reserve. Energy storage systems with nominal power capabilities of up to $60 \mathrm{MW}$, with a half-hour to an hour of storage capability, could meet the needs of a broad spectrum of utility sizes. Lead-acid batteries that are available or being developed are capable of meeting the spinning-reserve performance requirements.

Existing flooded-cell lead-acid batteries have been successfully demonstrated in this application in Berlin with a battery that has been operational for over six years in a combined spinning reserve and frequency regulation mode. In the U.S., there is a growing interest in BES systems. The Puerto Rico Electric Power Authority has undertaken construction of a $20 \mathrm{MW} / 14 \mathrm{MWh}$ battery to meet its spinning reserve needs. This battery is scheduled for commercial operation in the fall of 1993.

Frequency. Regulation. Fast-response energy storage systems can be used effectively to correct the frequency deviations that normally occur on the utility network as a result of momentary differences between system load and available generation resources. The requirements for a frequency regulation storage system are for rapid cycle-to-cycle discharge and rapid charge capability to compensate for a drop or rise in frequency on a continuous basis. The current lead-acid system being built by the Puerto Rico Electric Power Authority will also be used for this application, and other systems are planned.

The application of SMES for frequency regulation was demonstrated by an 8.3-kWh Los Alamos National Laboratory/Bonneville Power Administration (LANL/BPA) device in 1983. Operated intermittently for one year, the system accumulated over 106 cycles. This application demonstrated the rapid charge/discharge capability of the SMES system and its suitability for frequency regulation applications.

Power Quality. Industrial loads with large motors or other processes that require intermittent, sharp surges of power during their routine operation create brief voltage sags that affect power quality at the customer site and, depending on their severity, can also affect the power quality of neighboring customers. Voltage fluctuations and the resulting deterioration of power quality are becoming an increasingly important service issue as the use of sensitive electronic equipment increases. Power quality requires minimal energy storage. Both battery and SMES storage can be used effectively to provide this short-duration "pulse" discharge that lasts only a few seconds. 
Power quality applications require high power and low storage capacity, and commercially available SMES systems are technically suitable to meet the requirements. The key characteristic of the SMES system is its ability to charge and disisharge rapidly at high efficiency (>95\%) with virtually unlimited life. The power quality application utilizes this characteristic to its greatest advantage, and small SMES systems have been demonstrated at utility customer sites. Lead-acid batteries can also be used for this application, and their feasibility has been demonstrated in UPS applications.

Substation Applications. Substation energy storage requires systems in approximately the 2-to-10-MW power range, with up to $10 \mathrm{MWh}$ of storage capability. If the storage system is transportable, utilities can move the energy storage system to different sites as substation needs change in response to load-growth patterns over time.

Presently available lead-acid batteries can meet the needs of stationary substation energy storage. Transportability introduces new requirements for the system desigr. Improved lead-acid batteries and advanced batteries with small footprints are particularly desirable. Since substation-upgrade applications require storage capabilities of up to three hours, SMES is presently limited by its energy storage capacity and will require significant development to meet the needs of this application.

Renewables. Energy storage systems can potentially be an enabling technology that would facilitate the integration of renewable resources into the electric utility of the future. The value of renewable resources, especially photovoltaics and wind, is heavily dependent on their ability to generate energy when the utility system load peaks. The variability and unpredictability of these resources make it uncertain that their generation capability will be available to the utility on demand. If energy storage is available to a utility, however, the generation capacity of renewable resources is decoupled from the real-time energy needs of the utility network, and the energy generated can be stored for dispatch at any time.

Initially, for small pe ietration levels of renewable resources, the role that energy storage plays will be small. As the penetration level of renewable resources increases, the value and importance of energy storage to the utility network will be greatly enhanced. The performance characteristics required for renewable support are met by battery technology. SMES may not be suitable for this application at this time, and developing its capability to satisfy this application in a cost-effective manner will be a significant challenge. 


\section{TECHNOLOGY STATUS AND DEVELOPMENT NEEDS}

This section describes BES and SMES technology along with the development needs. Energy storage systems require a storage system la battery or a superconductor) and the associated hardware to allow the storage system to interface with the utility grid. The most important piece of hardware is the power conversion system. Figures 1 and 2 show complete BES and SMES systems.

\section{Storage Systerns}

Battery Systems. Battery systems store energy electrochemically, and the storage capacity of batteries depends on the electrochemical couple chosen. The energy stored in lead-acid batteries is approximately 30 to $40 \mathrm{Wh} / \mathrm{kg}$ or 60 to $100 \mathrm{Wh} / \mathrm{l}$. The energy conversion efficiency of lead-acid batteries is typically about 80 to $85 \%$. Lead-acid batteries are most readily available because of their other uses with proven reliability and low cost. Advanced batteries have the potential of doubling the capacity of lead-acid batteries and have a footprint that may be $25 \%$ of the size of lead-acid batteries.

The major concerns of utilities are the reliability (including lifetime) of battery systems, the maintenance requirements, and the footprint of the system. Lifetimes of batteries should be enhanced for improved lead-acid batteries like the VRLA and advanced batteries. Footprints can be decreased by $75 \%$ and energy densities at least doubled by advanced batteries. Demonstrations of standard designs of BES should demonstrate reliability and real maintenance rather than perceived maintenance requirements.

To enhance demonstration projects, development is needed in standardizing system designs for both stationary and transportable systems for both leadacid and advanced batteries. Transportable systems would meet short-term demonstration needs and also allow the utility to move the storage where it is most needed. Demonstrations will provide performance data needed for utility planners to consider battery energy storage as a viable option in their planning.

Superconducting Magnetic Energy Storage (SMES). This technology is based on storing energy in the magnetic field of a superconducting coil. Because direct current flows with negligible losses in superconductors, SMES systems can be used for small- and large-scale energy storage and rapid charge/discharge applications. 


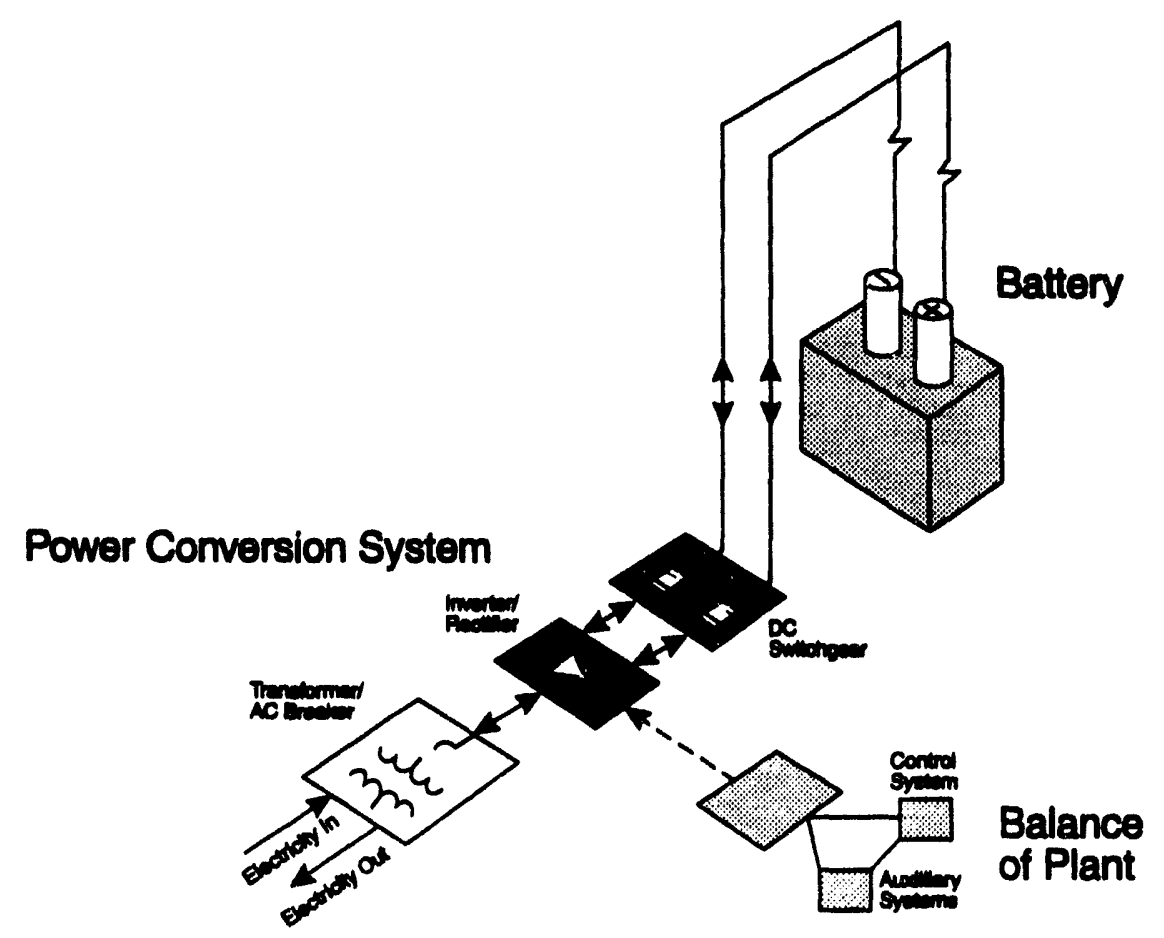

Figure 1. Schematic of a BES System

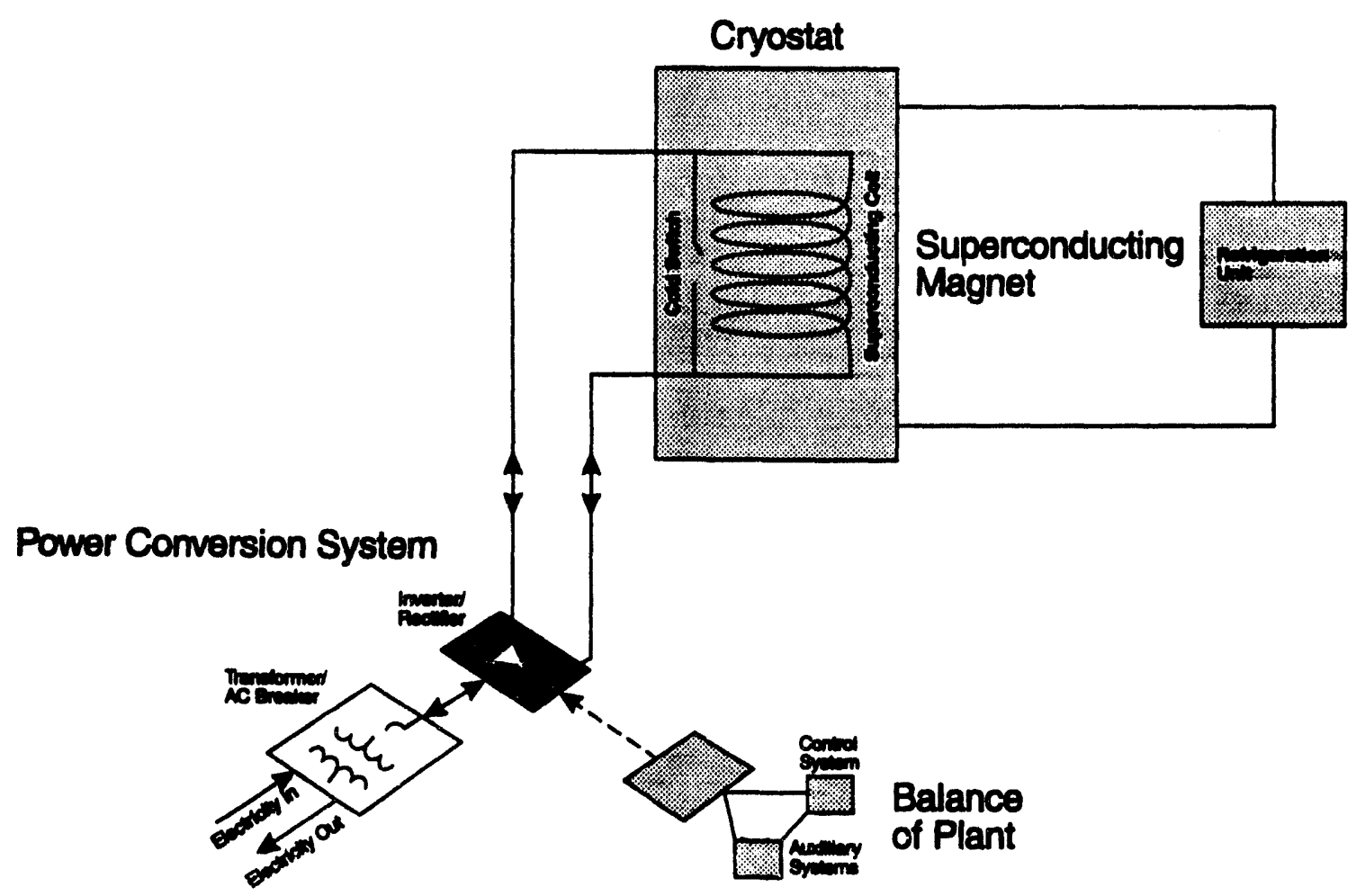

Figure 2. Schematic of a SMES System 
The primary components of a SMES system are

1. A magnet manufactured using either high-temperature or low-temperature superconducting wire.

2. A cryostat/refrigerator that maintains the superconducting materials at cryogenic temperatures. Typically, this is liquid helium $(4.2 \mathrm{~K})$ for lowtemperature superconductors (LTS), and it is projected to be liquid nitrogen (77 K) for high-temperature superconductors (HTS).

3. A structural support to contain the magnetic field (Lorenz forces, $(x B)$, which can be warm-supported (generally buried in the ground) or coldsupported (structural steel inside the cryostat).

Although few superconducting systems have been built for energy storage, commercially available low-temperature superconductors are used in medical and scientific instrumentation. They have also been proposed for use in the Supercollider. Development needs are minimal for low-temperature superconductors, but their use is limited by the high cost of helium and their refrigeration requirements.

High-temperature superconductors need significant development. One major hurdle is a method for processing the superconducting materials into the long flexible lengths of wire needed for the coils. This is particularly difficult because the superconductiv.cy depends not only on the exact formulation of the oxides, but the alignment of the crystals. Another priority is the development of very efficient refrigeration units.

\section{Power Conversion for BES and SMES}

A brief discussion of PCS basics is included here for completeness and to highlight the equally important development needs for this subsystem in the commercialization of both battery and SMES technologies.

Both batteries and SMES are dc power sources that require conversion to ac for interconnected or parallel operation with electric utilities. This conversion is performed by the PCS. The key component of the PCS is the inverter that converts the dc output of the storage device to ac during discharge and the ac to dc for recharging the storage device. Inverter design for either BES or SMES systems could be substantially similar except for its interface with the storage device. The battery, as seen by the PCS, behaves as a voltage source. The SMES coil, on the other hand, appears as a current source to the PCS. At present, there are no domestic or foreign PCS suppliers in the $40+\mathrm{MW}$ power rating. The self-commutated PCS sold to date for BESs have been one-of-a-kind, special-order units sold at premium cost. 
Both battery and SMES PCSs can be subdivided into two generic types. One type is switched or commutated by an external circuit, and the other type is switched of its own accord. The externally switched PCS, which relies on the electric utility line for switching or commutation, is called a linecommutated PCS; the internally switched PCS is called a self-commutated PCS. Power quality and frequency regulation are stand-alone operations isolated from the utility network and require self-commutated PCS capability.

Rapid advances in power conversion technology could have significant impact on self-commutated PCS designs. Until recently, Gate Turn Off (GTO) switches were preferred for high-rate PCS designs because of their higher power ratings. Integrated Gate Bipolar Transistors (IGBT), which were previously available only for lower power ratings, are now being designed for higher power ratings and offer operational as well as cost advantages over GTOs. Eventually, IGBTs or similar devices could replace GTOs as the preferred device for large PCSs. The fundamental circuit design of power conversion devices is also changing, and new circuits, such as the resonant frequency power converter, are being designed that have higher power capabilities and promise lower costs.

The development need is for a "commercial," self-commutated PCS for power quality, frequency-regulation applications, and renewables. Demonstrations of energy storage systems with this PCS are needed to establish its reliability. 


\section{Distribution}

ABB Power T\&D Co., Inc. (2)

630 Sentry Parkway

Blue Bell, PA 19422

Attn: P. Danfors

H. Weinrich

AC Battery Corporation

P.O. Box 325

East Troy, WI 53120

Attn: R. Flemming

Alaska Energy Authority

P.O. Box 190869

Anchorage, AK 99519-0869

Attn: D. Denig-Chakroff

American Electric Power Service Corp.

1 Riverside Plaza

Columbus, OH 43215

Attn: C. Shih

Argonne National Laboratories (3)

CTD, Building 205

9700 South Cass Avenue

Argonne, IL 60439

Attn: C. Christianson

W. Deluca

K. Myles

Arizona Public Service

P.O. Box 5399

Phoenix, AZ 85072

Attn: R. Hobbs

AT\&T Energy Systems

3000 Skyline Drive

Mesquite, TX 75149

Attn: M. Bize

Bechtel

P.O. Box 193965

San Francisco, CA 94119-3965

Attn: W. Stolte

Bonneville Power Administration

Routing EO

P.O. Box 3621

Portland, OR 97208

Attn: J. Ray
C\&D Charter Power Systems, Inc.

3043 Walton Road

P.O. Box 239

Plymouth Meeting, PA 19462-0239

Attn: S. Misra

California State Air Resources Board

Research Division

P.O. Box 2815

Sacramento, CA 95812

Attn: J. Holmes

Chugach Electric Association, Inc.

P.O. Box 196300

Anchorage, AK 99519-6300

Attn: T. Lovas

Consolidated Edison (2)

4 Irving Place

New York, NY 10003

Attn: M. Lebow

N. Tai

Corn Belt Electric Cooperative

P.O. Box 816

Bloomington, IL 61702

Attn: R. Stack

Decision Focus, Inc.

650 Castro Street, Suite 300

Mountain View, CA 94041

Attn: S. Jabbour

Delco-Remy

7601 East 88th Place

Indianapolis, IN 46256

Attn: R. Rider

Doug Danley

18131 Metz Dr.

Germantown, MD 20874

Eagle-Picher Industries

C \& Porter Street

Joplin, MO 64802

Attn: J. DeGruson 
East Penn Manufacturing Co., Inc.

Deka Road

Lyon Station, PA 19536

Attn: M. Stanton

Electric Power Research Institute (6)

3412 Hillview Avenue

P. O. Box 10412

Palo Alto, CA 94303

Attn: J. Birk

S. Chapel

S. Eckroad

R. Schainker

P. Symons

R. Weaver

Electrotek Concepts, Inc.

P.O. Box 16548

Chattanooga, TN 37416

Attn: H. Barnett

Eltech Research Corporation

625 East Strect

Fairport Harbor, $\mathrm{OH} 44077$

Attn: E. Rudd

Energetics, Inc. (5)

7164 Columbia Gateway Drive

Columbia, MD 21046

Attn: J. Badin

D. Baker

J. Hurwitch

C. Matzdorf

P. Taylor

Energy Systems Consulting

41 Springbrook Road

Livingston, NJ 07039

Attn: A. Pivec

Exxon Research Company

P.O. Box 536

1900 East Linden Avenue

Linden, NJ 07036

Attn: P. Grimes

Firing Circuits, Inc.

P.O. Box 2007

Norwalk, CT 06852-2007

Attn: J. Mills
General Electric Company (2)

Building 2, Room 6u5

1 River Road

Schenectady, NY 12345

Attn: E. Larson

D. Swann

General Electric Drive Systems

1501 Roanoke Blvd.

Salem, VA 24153

Attn: C. Romeo

Giner, Inc.

14 Spring Street

Waltham, MA 02254-9147

Attn: A. LaConti

GNB Industrial Battery Company (3)

Woodlake Corporate Park

829 Parkview Blvd.

Lombard, IL 60148-3249

Attn: S. Deshpande'

G. Hunt

J. Szymborski

Hawaii Electric Light Co.

P.O. Box 1027

Hilo, HI 96720

Attn: C. Nagata

Hughes Aircraft Company

P.O. Box 2999

Torrance, CA 90509-2999

Attn: R. Taenaka

Integrated Power Corp.

7524 Standish Place

Rockville, MD 20855

Attn: J. Adelman

ILZRO

P.O. Box 12036

Research Triangle Park, NC 27709

Attn: R. Nelson

Johnson Controls Battery Group, Inc. (4)

5757 N. Green Bay Avenue

P. O. Box 591

Milwaukee, WI 53201

Attn: P. Eidler

R. Miles

T. Ruhlmann

W. Tiedeman 
Johnson Controls Battery Group, Inc.

12500 W. Silver Spring Drive

P. O. Box 591

Milwaukee, WI 53201-0591

Attn: J. Zagrodnik

Lawrence Berkeley Laboratory (3)

University of California

One Cyclotron Road

Berkeley, CA 94720

Attn: E. Cairns

K. Kinoshita

F. McLarnon

Jo Meglen

P.O. Box 3232

Oakton, VA 22124

N.E.T.S.

P.O. Box 32584

Juneau, AK 99803

Attn: T. Neubauer

National Renewable Energy Laboratory (3)

1617 Cole Blvd.

Golden, CO 80401-3393

Attn: R. McConnell

J. Ohi

N. Rau

New York Power Authority

1633 Broadway

New York, NY 10019

Attn: B. Chezar

Northern States Power

414 Nicollet Mall

Minneapolis, MN 55401

Attn: M. Rogers

Oak Ridge National Laboratory

P.O. Box 2008

Oak Ridge, TN 37831

Attn: B. Hawsey, Bldg. 3025, MS-6040

J. Stoval, Bldg. 3147, MS-6070

J. VanCoevering, Bldg. 3147, MS-6070

Oglethorpe Power Company (2)

2100 E. Exchange Place

P.O. Box 1349

Tucker, GA 30085-1349

Attn: K. Scruggs

C. Ward
Omnion Power Corporation (2)

P.O. Box 879

East Troy, WI 53120

Attn: H. Meyer

F. Ruf

Pacific Gas \& Electric (3)

3400 Crow Canyon Road

San Ramon, CA 94583

Attn: G. Ball

B. Norris

R. Winter

Pacific Northwest Laboratory (2)

Battelle Blvd.

Richland, WA 99352

Attn: J. DeSteese, K5-02

K. Drost

Power Technologies, Inc.

1482 Erie Blvd.

P.O. Box 1058

Schenectady, NY 12301

Attn: P. Prabhakara

Power Technologies, Inc.

775 Sunrise Ave.

Suite 210

Roseville, CA 95661

Attn: H. Clark

Puerto Rico Power Authority

G.P.O. Box 4267

San Juan, Puerto Rico 00936-426

Attn: W. Torres

R\&D Associates

2100 Washington Blvd.

Arlington, VA 22204-5706

Attn: J. Thompson

Robicon Corporation

100 Sagomore Hill Road

Pittsburgh, PA 15239

Attn: A. Maruschak

Sacramento Municipal Utility District

6201 S. Street

Sacramento, CA 95817

Attn: L. Wittrup

Salt River Project

MS PAB 357, Box 52025

Phoenix, AZ 85072-2025

Attn: H. Lundstrom 
San Diego Gas \& Electric Company (2)

P.O. Box 1831

San Diego, CA 92112

Attn: T. Nelson

J. Wight

W. J. Schafer Associates

303 Lindbergh Avenue

Livermore, CA 94550-9551

Attn: S. Schoenung

R. K. Sen \& Associates 3808 Veazey Street NW Washington, DC 20016

Attn: R. Sen

Silent Power, Inc. 163 West 1700 South Salt Lake City, UT 84115

Attn: J. Rassmussen

Silent Power, Inc. 489 Devon Park Drive

Suite 315

Wayne, PA 19087

Attn: W. Auxer

Silent Power, Ltd.

Davy Road, Astmoor

Runcorn, Cheshire

UIITED KINGDOM WA7 1PZ

Attn: M. McNamee

Southern California Edison (2)

2244 Walnut Grove Avenue

P.O. Box 800

Rosemeade, CA 91770

Attn: A. Rodriguez

R. Scheffler

SRI International 333 Ravenswood Ave.

Menlo Park, CA 94025

Attn: C. Seitz

Stuart Kuritzky

347 Madison Avenue

New York, NY 10017

Superconductivity, Inc. 2114 Eagle Drive Middleton, WI 53562

Attn: J. Emerick
United Engineers and Contractors

700 South Ash St.

P.O. Box 5888

Denver, CO 80217

Attn: A. Randall

University of Missouri - Rolla

112 Electrical Engineering Building

Rolla, MO 65401-0249

Attn: M. Anderson

University of Wisconsin - Madison

Dept. of Electrical \& Computer Eng.

1415 Johnson Drive

Madison, WI 53706

Attn: D. Divan

U.S. Department of Energy

Energy Information Administration

EI-531 FORSTL

Washington, DC 20585

Attn: T. Petersik

U.S. Department of Energy

Office of Energy Management

EE-14 FORSTL

Washington, DC 20585

Attn: M. Gunn

U.S. Department of Energy (21)

Office of Energy Management

EE-142 FORSTL

Washington, DC 20585

Attn: R. Eaton (20)

N. Rossmeissl

U.S. Department of Energy

Office of Propulsion Systems

EE-321 FORSTL

Washington, DC 20585

Attn: A. Landgrebe

U.: Department of Energy

Albuy. rque Operations Office

Energy Technologies Division

Albuquerque, NM 87115

Attn: G. Buckingham

U.S. Windpower, Inc.

6952 Preston Avenue

Livermore, CA 94550

Attn: B. Erdman 
Westinghouse STC

1310 Beulah Road

Pittsburgh, PA 15235

Attn: H. Saunders

W. R. Grace \& Company

62 Whittemore Avenue

Cambridge, MA 02140

Attn: S. Strzempko

Yuasa-Exide

P.O. Box 14205

Reading, PA 19612-4205

Attn: F. Tarantino

Zaininger Engineering Co., Inc. 1590 Oakland Road, Suite B211

San Jose, CA 95131

Attn: H. Zaininger

2000 H. Schmitt

2200 R. Bair
10214 J. Kerr, Attn: D. Wilt

6200

6213

6218

6218

8111

8300

8523-2 Central Technical Files

7141 Technical Library (5)

7151 Technical Publications

7613-2 Document Processing for DOE/OSTI (10) 


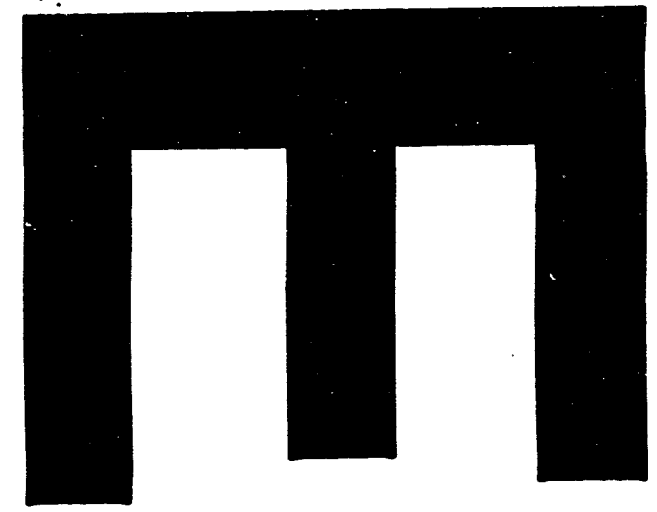

9
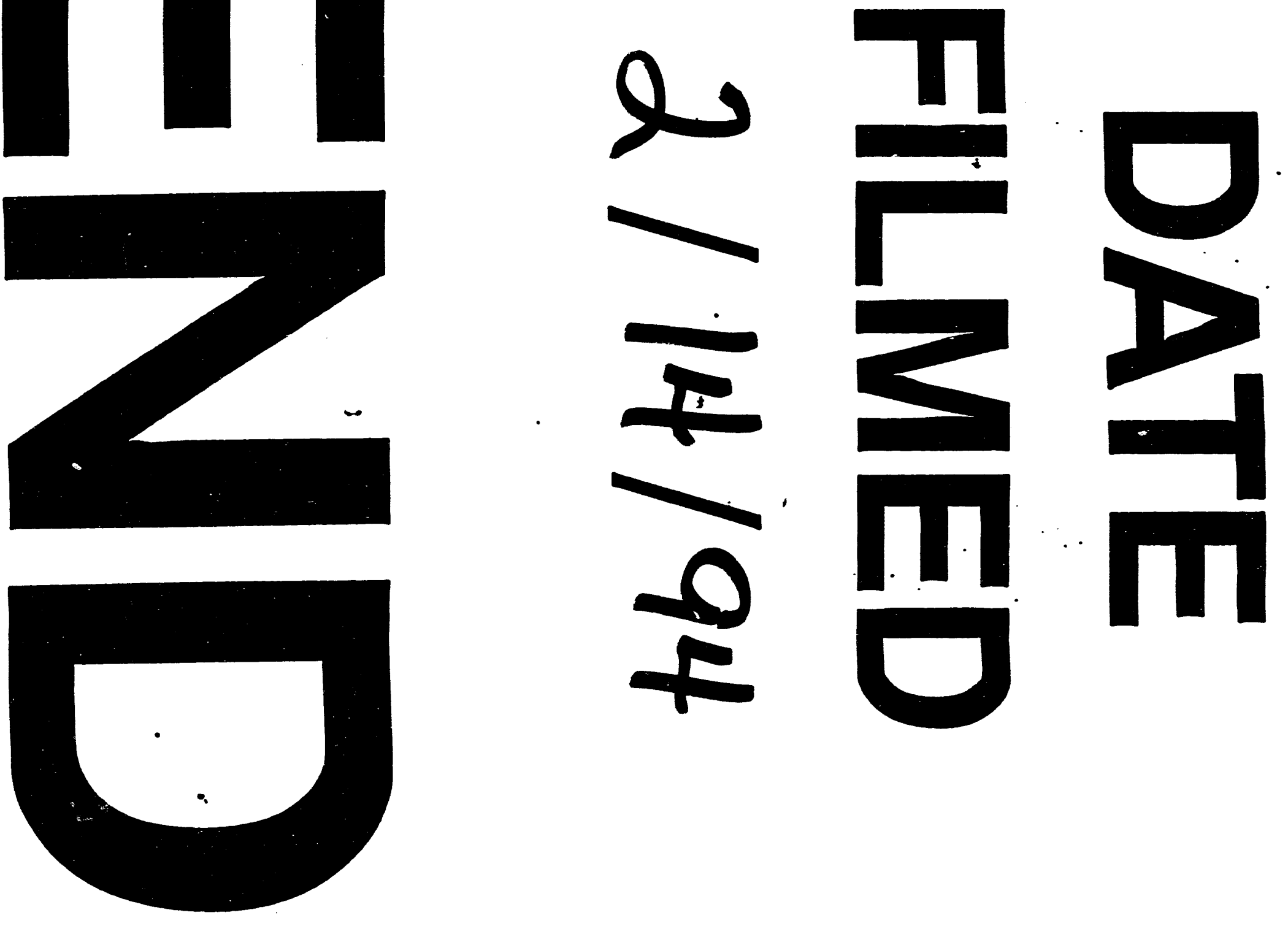
